\title{
Charles Armitage Brown, John Keats and Plymouth ${ }^{1}$
}

\author{
NichOLAS RoE \\ University of St Andrews
}

\begin{abstract}
In the mean time I will tell you about our Plymouth Institution. We have many literary and scientific men here, three rather high in fame, and they are members. During the six winter months we have a lecture and an after discussion there every Thursday, and during the summer tea and coffee once a month to keep us together and settle various points. The building is very handsome, of Grecian architecture. Ill as I was, some how I ventured to get up with a speech in my mouth before a hundred strangers, - (I that never had spoken ten words before ten such!) — and, to my surprise, made an impression. I am now hand in hand with them. In March, just as their season was ending, they were disappointed of a lecture; when I, bettering in health, read them one on "Shakespear's Sonnets". I am down for one next November on "The intellectual history of Florence", and, if I wanted, for another on "The influence of Italian on English poetry". This Institution suits me to a hair. I have lately been made their librarian. Every summer, (and this is a third) the Institution is opened as a gallery of paintings and drawings by resident and other artists, - and I am on the Committee, — nay, on the hanging one. I shall send my Hogarths, my two portraits of Keats from you, and the medallion in plaister of him by Girometti, which Woodhouse gave me; and also Kirkup's drawings of yourself and Carlino, $-[\ldots]$ you will be exhibited at Plymouth! ${ }^{2}$
\end{abstract}

So Charles Armitage Brown wrote to Joseph Severn, a resident at Rome since John Keats's death there in 1821 . He outlined with evident pleasure the Institution's calendar of activities, his contributions as a speaker and role on the 'Hanging Committee'. His lecture about Shakespeare's sonnets would evolve into his pioneering study Shakespeare's Autobiographical Poems $(1838)^{3}$; the other two lectures that he mentioned drew upon his fourteen years in Italy at Pisa, Rome and Florence (1822-36). Now back in England, Brown had settled at Plymouth, apparently to be near relatives and to find a career for his teenage son, Carlino. The climate was thought to be an advantage, and he anticipated 'excellent society, whether for literature, science, or the fine arts [...] within a distance of

\footnotetext{
${ }^{1}$ A talk given at the Plymouth Athenaeum on Friday 28 October 2016.

2 To Joseph Severn, 31 May 1836; New Letters from Charles Brown to Joseph Severn, Letter 40, ed. Grant F. Scott and Sue Brown. http://www.rc.umd.edu/editions/brownsevern/

${ }^{3}$ Shakespeare's Autobiographical Poems. Being his Sonnets Clearly Developed: with His Character Drawn Chiefly from his Works (London, 1838).
} 
about twenty hours from the great market, London, — thanks to our rapid travelling by steam!'4 At Plymouth the focus of cultured society was the Institution and its neoclassical Athenaeum (Figures 6.2, 6.3).

Sessions commenced each year in October and continued through the following five months with a lecture every Thursday evening from 7 to 8 o'clock and two further hours of discussion. ${ }^{5}$ Brown would become Curator of the Institution's Library (1836-7) then Vice-President (1837-9), and by 1839 he had delivered seven lectures:

10 March 1836: 'Sonnets of Shakespeare'.

10 November 1836: 'Literary History of Florence'.

29 December 1836: 'On the Life and Poems of John Keats'.

19 October 1837: 'The Learning of Shakespeare'.

26 October 1837: 'On Shakespeare in Reference to his Knowledge and Dramatic Art'.

8 February 1838: 'Milton's Comus'.

4 April 1839: 'Influence of Italian on English Literature'. ${ }^{6}$

\begin{abstract}
$* * *$
'Now for my cottage', Brown's letter to Severn continues:

it is two miles from the town, near the Exeter road, and the Laira, an arm of the sea. Laira Green consists of six gentlemen's cottages, one of which is mine. It has two gardens, of altogether a fifth of an acre. An avenue, planted with trees and shrubs, runs before the cottages [...] Behind, to the north, is an abrupt rock, topped by a hill. The spot is almost proverbially healthy, and, from its sheltered situation, warm. ${ }^{7}$
\end{abstract}

John Cooke's 1820 map of the 'Borough of Plymouth' shows the original Athenaeum at the centre left. Two miles from town, Brown's new home was — and still is — located just

\footnotetext{
${ }^{4}$ Charles Brown to Joseph Severn, 17 March 1835, New Letters from Charles Brown to Joseph Severn, Letter 39. Presumably Brown means rapid travelling by steam packet from Plymouth to London; the rail link between Plymouth and Exeter (and onwards to London) was not opened until May 1848. Its original station was close to Brown's home at Laira.

${ }^{5}$ Nettleton's Guide to Plymouth, Stonehouse, Devonport, and to the Neighbouring Country (Plymouth, 1836), 18.

6 'A List of the Lectures Delivered to the Members of the Plymouth Institution from The Commencement of the Session 1833-34 to the End of the Session 1854-55', Annual Reports and Transactions of the Plymouth Institution and Devon and Cornwall Natural History Society, Volume 4, 1869-73 (Plymouth, 1873), 155-62. Thanks to Ben Serpell of the Plymouth Athenaeum for details of these lectures.

${ }^{7}$ Charles Brown to Joseph Severn, 31 May 1836, New Letters from Charles Brown to Joseph Severn, Letter 40.
} 
off the Old Laira Road, in the angle between 'Richmond Cot' and the Dartmoor Rail Road heading north from the quay at Sutton Pool to the quarries at Princetown (Figures 6.4, 6.5, 6.6). ${ }^{8}$ I recall playing on the flat granite flagstones of this old Rail Road, up on the moor above our home at Ling Cottage in Clearbrook - the stones are still clearly visible now, running between the Devonport Leat (1802) and Sir Francis Drake's sixteenth-century Plymouth Leat (Figure 6.7). I was just seven years old, and to find the Dartmoor Railroad so close to Charles Brown's house at Laira Green lays down stepping-stones between 1836, 1962, and 2016.

Here is Brown's inventory of his new home:

On the ground floor we have two parlours, with the roses looking in at the windows, two kitchens, a china closet, a pantry, and every convenience, with hard and soft water [...] Up stairs we have four good bedrooms; - the servant sleeps now in the kitchen, but a fifth bedroom will be made at a trifling expence. I likewise intend to build a small green-house, since perfect happiness cannot be attained without it. The views and the country about us are delightful. There are plenty of fruits, flowers, and shrubs in the garden; for it has been carefully tended. Now for all this what think you do I pay? - £18 a year. ${ }^{9}$

Returned from Italy, Brown was now well settled in Laira Green. He was a Shakespeare scholar, keen on theatregoing; an accomplished amateur artist; a would-be playwright and novelist; a gardener and an intrepid long-distance walker. ${ }^{10}$ Brown was also one of the first 'Keatsians'. He had known John Keats, and shared his house with him for two years (181820); he had also met many of the leading writers of the day including Lord Byron, Leigh Hunt, William Hazlitt and Percy and Mary Shelley. Sociable, self-confident and opinionated, he enjoyed discussion and debate and had quickly settled into his new life at the Plymouth Institution.

\footnotetext{
${ }^{8}$ Now Cleve Villa on Laira Avenue.

${ }^{9}$ Charles Brown to Joseph Severn, 31 May 1836, New Letters from Charles Brown to Joseph Severn, Letter 40.

${ }^{10}$ When Brown emigrated to New Zealand in 1841 he took his extensive collection of play scripts with him; they are now in the library at Puke Ariki, New Plymouth. ARC2011-112 'The personal library of Charles Armitage Brown and Thomas King'.
} 
Born at Lambeth on 14 April 1787, Charles Brown was the sixth son of William Brown, a Scots broker, and his Welsh wife Jane Armitage. Little is known about his early life, although it is said that he attended school with Charles Wentworth Dilke — the son of Charles Wentworth Dilke Snr., a clerk at the Admiralty and his wife Sarah. ${ }^{11}$ At fourteen years old Brown was working in a counting-house, then joined his older brother John at St. Petersburg trading bristles for the London market. With prosperity came his engagement to a Miss Kennedy — but then the business failed and he came back to London alone - a twenty-one-year-old bankrupt. For four years he seems to have lived in penury, being too independent or stubborn to seek assistance, until he became a London representative for another brother, James, of the East India Company. Bankruptcy proved to be surprisingly bankable, in that Brown had used the time to compose a comic opera, Narensky, or, the Road to Yaroslaf, staged at Drury Lane in January 1814 (Figure 6.8).

'It is endurable', a reporter from The Morning Post decided:

But when we say this, we say nearly all that can be said in its favour. [...] They drink and sing, brandish swords and pistols with bottles and glasses, and close the jovial scene by sallying forth [...] In this there can be nothing new, but it is that of which an English audience is never tired. ${ }^{12}$

Narensky was a hit. A dozen nights at Drury Lane netted Brown $£ 300$ and a 'silver ticket' granting him free entry to the theatre for life. It seems likely that a further windfall, and some property, came to Charles at the death of his brother James, and by 1816 he was living in one half of Wentworth Place, a large new-build house on the southern edge of Hampstead Heath. Wentworth Place was actually two semi-detached houses; it contained Brown's home and, separated by an interior wall, his school friend Dilke's family home with his wife Maria and their son.

\footnotetext{
${ }^{11}$ The standard biography of Brown is E. H. McCormick, The Friend of Keats. A Life of Charles Armitage Brown (Wellington, 1989).

${ }^{12}$ The Morning Post (12 January 1814).
} 
The three Keats brothers had entered Charles Brown's life through the other half of Wentworth Place. 'John George \& Tom were with me three times a week, often three times a day', his neighbour Dilke recalled. ${ }^{13}$ At this time the brothers were living half a mile away at Well Walk, Hampstead, and it was through these visits that John Keats eventually met Brown. Dilke recalled that Brown and Keats 'were drawn together by force of circumstances' although Brown himself recollected a more decisive first encounter. ${ }^{14}$ Somewhere between Well Walk and Wentworth Place one day in late summer 1817, Keats met Brown on the Hampstead Road. It was a moment Brown never forgot, and he wrote about it 19 years later: 'In the latter part of that year's summer I first saw him. It was on the Hampstead road that we were introduced to each other; the minutest circumstances attending our first meeting are strong in my memory $[\ldots]$ [and] in that interview of a minute I inwardly desired his acquaintanceship, if not his friendship' ${ }^{15}$ The meeting led to a close friendship of immense importance to Keats — and to us. Brown became Keats's constant friend, collaborator and adviser — indeed Richard Holmes has speculated on a much closer bond, 'a truly intimate friendship, emotionally more intense than either would quite admit' ${ }^{16}$ Brown's self-portrait, painted around the time he first met Keats, shows a young man in his late twenties with reddish brown hair brushed over a wide forehead, pale blue eyes, forthright nose and firm mouth — all features that reappear in the bust, by an unknown sculptor, dating from 1830. ${ }^{17}$ Brown's descendant Helen Baker strikingly resembles her ancestor as seen in the self-portrait (Figure 6.9) and in the bust (Figure 6.10).

\footnotetext{
${ }^{13}$ The Keats Circle: Letters and Papers 1816-1878 and More Letters and Poems 1814-1879, ed. Hyder Edward Rollins ( $2^{\text {nd }}$ edn., 2 vols, Cambridge, MA, 1965), ii. 104-5, hereafter $K C$.

${ }^{14} \mathrm{KC}$, ii. 105.

15 'Charles Brown: Life of John Keats 19 March 1841', KC, ii. 57.

${ }^{16}$ Richard Holmes, 'John Keats the Well-Beloved', This Long Pursuit. Reflections of a Romantic Biographer (London, 2016), 239.

${ }^{17}$ Brown's self-portrait appears here by kind permission of Yvonne King of New Plymouth, New Zealand.
} 
Keats gleefully penned a satirical portrait of 'C.B.' as a thin, lifeless, 'melancholy carle':

Ne cared he for wine, or half and half, Ne cared he for fish, or flesh, or fowl, And sauces held he worthless as the chaff [...]

The slang of cities in no wise he knew, Tipping the wink to him was heathen Greek; He sipp'd no olden Tom, or ruin blue, Or nantz, or cherry brandy, drank full meek By many a damsel hoarse and rouge of cheek;

Nor did he know each aged watchman's beat $[\ldots]^{18}$

Brown was a bon viveur, and kept a good cellar of wine in the basement of his home (it can still be seen at Keats House, Hampstead - extending under the back lawn, without the bottles). He was wealthy enough to appear as a man of independent means, free to cultivate literary pursuits and indulge his taste for 'blue ruin' and 'nantz' — gin and brandy. He did a little tutoring, and in the summer months would let out his half of Wentworth Place and go north to walk around Scotland. He married his house servant, Abigail Donaghue, by whom he had one son, Carlino, but they seem never to have lived together as a family. Up to a point Keats was amused by Brown's flirtatiousness: 'When I come to town', he told Dilke, 'I shall have a little talk with you about Brown and one Jenny Jacobs. Open daylight! He don't care'. ${ }^{19}$ The jokes stopped, though, when Brown tried flirting with Fanny Brawne.

$* * *$

Brown was the only person to witness the composition of some of Keats's greatest and most enduring poems - The Eve of St Agnes, Hyperion, 'La Belle Dame sans Merci', the 'Nightingale Ode', Lamia and, perhaps, 'To Autumn'. He made a fine pencil sketch of Keats while they were at Shanklin on the Isle of Wight in summer of 1819 (Figure 6.11).

\footnotetext{
${ }^{18}$ The Poems of John Keats, ed. Jack Stillinger (Cambridge, MA, 1978), 326-7, lines 10-12, 19-24.

${ }^{19}$ Letters of John Keats, 1814-1821, ed. Hyder E. Rollins (1958; 2 vols, Harvard MA, 1972), ii. 136, hereafter LJK.
} 
When they first met, Keats was 21 . He had abandoned his medical training at Guy's Hospital and his first book, Poems, by John Keats had been published in March 1817. Since then he had been at work on his 'poetic romance' Endymion. Keats and his brothers and sister had been orphaned in childhood, and each had been left a considerable legacy by their grandparents — for John, much of this inheritance had seen him through medical school. Now, his ambitions had turned to poetry and ideas of 'fame'; he was determined, as he said, to 'gain [his] Living' by poetry, and to be 'among the English Poets' ${ }^{20}$

Keats saw in Brown an older brother figure, experienced and wordly-wise; Brown saw a young genius 'dearly beloved, and honoured as a superior being by me', as he later said. ${ }^{21}$ When George Keats and his wife determined to emigrate to America, it was Brown and Keats who accompanied them to Liverpool to bid farewell, on what proved to be a first leg of an epic walking tour that would take them on foot from the Lake District to Scotland, through the western highlands to Oban, across Mull to Iona and Fingal's Cave on Staffa, up Ben Nevis, then along the Great Glen to Inverness. It was Brown who took on the role of Boswell, keeping a detailed day-to-day record of their progress. Keats's letters, in turn, give us glimpses of Brown:

Brown was knock'd up from new shoes [...] with his feet blistered and scarcely able to walk, after a trudge of 20 Miles down the Side of Loch Awe [...] [we] had no supper but Eggs and Oat Cake — we have lost the sight of white bread entirely-

Brown keeps on writing volumes of [our] adventures to Dilke- - when we get in of an evening and I have perhaps taken my rest on a couple of Chairs he affronts my indolence and Luxury by pulling out of his knapsack $1^{\text {st }}$ his paper $-2^{\text {ndy }}$ his pens and last his ink - Now I would not care if he would change about a little-I say now, why not ... take out his pens first sometimes-But I might as well tell a hen to hold up her head before she drinks instead of afterwards.

For some days Brown has been enquiring out his Genealogy here- he thinks his Grandfather came from long Island - he got a parcel of people about him at a Cottage door last Evening - chatted with ane who had been a Miss Brown and who I think from a likeness must have been a Relation — he jawed with the old

\footnotetext{
${ }^{20} K C$, i. 307 ; $L J K$, i. 394.

21 'Life of Keats', $K C$, ii. 54.
} 
Woman - flatterd a young one - kissed a child who was affraid of his Spectacles and finally drank a pint of Milk-They handle his Spectacles as we do a sensitive leaf. $^{22}$

At Inverness Keats was ill with a sore throat, and immediately returned to London by sea. Back in Hampstead he found his youngest brother, Tom, dying of consumption. Keats nursed him throughout the Autumn, most likely contracting the disease as he did so; following Tom's death on 1 December, he accepted Brown's invitation to move in with him at Wentworth Place.

From this time until Keats left for Italy in September 1821, Brown and Keats were almost constantly together. In January of 1819 they both went to Chichester and the Old Mill House at Bedhampton, where Keats composed The Eve of St Agnes on sheets of thin paper he had brought from London. In May that year it was Brown who ensured the survival of one of Keats's odes, leaving us this record of how Keats composed:

[E]very short poem [...] was scrawled on the first piece of paper at hand, and [...] afterwards used as a mark to a book, or thrust any where aside. In the spring of 1819 a nightingale had built her nest near my house [...] and one morning he took his chair from the breakfast-table to the grass-plot under a plum-tree, where he sat for two or three hours. When he came into the house, I perceived he had some scraps of paper in his hand, and these he was quietly thrusting behind the books. On inquiry, I found those scraps, four or five in number, contained his poetic feeling on the song of our nightingale. The writing was not well legible; and it was difficult to arrange the stanzas on so many scraps. With his assistance I succeeded, and this was his Ode to a Nightingale. ${ }^{23}$

Thanks to Brown, we know that this poem sprang from a single creative impulse; 'not well legible' registers imaginative pressure, as do the disarranged pieces of paper. Keats said that he composed 'half at Random', ${ }^{24}$ and Brown's account fits such a scenario; it also suggests that Keats may have found difficulty in resuming work on a poem after an initial impulse had lapsed. Repeated interruptions to the flow of composition may explain, in part, why he was unable to proceed further with his epic Hyperion. From this moment onwards,

${ }^{22} L J K$, i. 336-8; 344; 347.

23 'Life of Keats', $K C$, ii. 65.

${ }^{24} L J K$, i. 142. 
Brown was allowed to copy any verses Keats wrote, and his transcripts are now in the Keats collection at Harvard University Library.

Other insights Brown offers are his recollection that Keats was 'secretly taking, at times, a few drops of laudanum', and that he had warned him against such a habit. ${ }^{25}$ Then there is Brown's curious transcript from one of Keats's letters that has since been lost: 'I shall make some confession', Keats writes to Brown,

which you will be the only person, for many reasons, I shall trust with. A winter in England would, I have not a doubt, kill me; so I have resolved to go to Italy, either by sea or land. Not that I have any great hopes of that,--for, I think, there is a core of disease in me not easy to pull out. * (Note) X X X X X X X X X X X X X X X If I should die X X X X X

Brown commented on this passage as follows: '*(Note) The omitted passage contained the secret. He went to Italy in pursuance of his physician's urgent advice'. ${ }^{26}$ What Keats's 'secret' may have been is not apparent; that it was 'his engagement to Fanny Brawne' seems unlikely, and as the original letter has disappeared it is not possible to examine the passage omitted in Brown's transcript. ${ }^{27}$ Possibly this 'secret' was connected with Brown's recollection of Keats 'secretly taking' laudanum; if so, could the further 'secret' be doses of mercury to cure his 'core of disease'?

In summer of 1819 Brown was with Keats on the Isle of Wight, where they collaborated on a play, Otho the Great, and then at Winchester where Keats wrote his last great poem, To Autumn — aware by now that he was seriously unwell. Not long afterwards, in January 1820, Brown witnessed Keats's first tubercular haemorrhage and recorded what he said: 'I know the colour of that blood; - it is arterial blood;- - I cannot be deceived in that colour; - that drop of blood is my death-warrant' ${ }^{28}$ Keats recovered in the

\footnotetext{
${ }^{25} K C$, ii. 73.

${ }^{26} K C$, ii. $78-9$.

${ }^{27}$ See $K C$, ii. 78, and Life of John Keats by Charles Armitage Brown, ed. Dorothy Hyde Bodurtha and Willard Bissell Pope (Oxford, 1937), 69, 115, hereafter Life of John Keats by Charles Armitage Brown.

${ }^{28} \mathrm{KC}$, ii. 73-4.
} 
following spring, and was well enough to accompany Brown down the Thames to Gravesend as he set off by sea for his annual summer walking tour. 'This was on the $7^{\text {th }}$ May', Brown later remembered, adding: 'I never saw him afterwards' ${ }^{29}$ Keats left for Italy four months later, before Brown returned from the north, and died at Rome on 23 February 1821. His last letter, dated from Rome on 30 November, was to Brown: 'I can scarcely bid you good bye even in a letter. I always made an awkward bow. God bless you! John Keats' ${ }^{30}$

A few weeks after Keats's death his publisher advertised that the Memoirs and Remains of John Keats would be speedily published, with a portrait — an 'indecent bustle', in Brown's view (Figure 6.12). ${ }^{31}$ When Taylor's Memoirs did not appear, George Keats recommended Charles Wentworth Dilke or John Hamilton Reynolds as in 'every way Competent' to write his brother's biography. ${ }^{32}$ Leigh Hunt included a chapter on Keats in Lord Byron and some of his Contemporaries (1828) — 'worse than disappointing' was Brown's somewhat bleak verdict. ${ }^{33}$ Keats's friend and mentor at Enfield, Charles Cowden Clarke, eventually published his own 'Recollections of Keats by an old Schoolfellow', but that was in 1861, 40 years after Keats's death. ${ }^{34}$

Only Brown had day-by-day and sometimes hour-by-hour memories of Keats's life and writing in the years 1817-20. He had a collection of his own transcripts of Keats's poems, and a bundle of letters and papers Keats had taken to Rome, given to him by Joseph Severn. ${ }^{35}$ Yet Brown paused, initially finding the prospect of writing a biography too

\footnotetext{
${ }^{29} \mathrm{KC}$, ii. 74.

${ }^{30} \mathrm{LJK}$, ii. 360.

${ }^{31}$ The Letters of Charles Armitage Brown, ed. Jack Stillinger (Cambridge, MA, 1966), 89, hereafter LCAB; Morning Chronicle (4 June 1821).

${ }^{32} K C$, i. $288,329$.

${ }^{33} L C A B, 295$.

${ }^{34}$ Atlantic Monthly (January 1861), 86-100.

${ }^{35}$ See John Barnard, 'Which Letters did Keats take to Rome?', Keats-Shelley Journal, 64 (2015), 72-91.
} 
painful, and then reluctant to publish until the public had already begun to appreciate Keats's genius. The copyright to Endymion and Lamia, Isabella, The Eve of St Agnes and other Poems lay with Keats's publishers, Taylor and Hessey, and George Keats had forbidden Brown to publish any of his brother's poems in his possession. ${ }^{36}$ It was Brown, nevertheless, who insisted that Keats's 'dying request' must be honoured: 'that his name should not be on his tombstone, and that the words "Here lies one whose name was writ in water" should be there'. ${ }^{37}$

Brown had made a start on his memoir of Keats at Florence in 1829-30, although it was not until November 1836 at Plymouth that he announced: 'I boldly put down my name at our Institution for a lecture, on 29 December, on "The life and poems of John Keats". Now that it is advertised, the card printed, the members looking forward to it, there is no retreating, it must be done'. ${ }^{38}$

'It had a remarkable reception at our Institution', Brown told Leigh Hunt in a letter of 10 June 1837, 'but, I have been told, less on his account as a poet than on account of its interest as a piece of biography, read by the friend of a young poet - no matter who it was [...] Coleridge's son [Derwent Coleridge] was there, and he was the only person (as well as parson) present who had read his poems, - he was enthusiastic in their praise'. ${ }^{39}$ Brown's lecture at the Plymouth Institution (Figure 6.13) was therefore a momentous contribution to the development of Keats's reputation. It was the first public lecture on Keats, drawn from the first full-length biography of him. And there was more: one of Brown's first actions on the Hanging Committee was to exhibit his copies from Hogarth, his two portraits of Keats by Joseph Severn, the medallion of Keats by Giuseppe Girometti (Figure 6.14), and Seymour Kirkup's drawings of Severn and Carlino. In 1836 these portraits formed the

\footnotetext{
${ }^{36}$ See Lawrence M. Crutcher, George Keats of Kentucky. A Life (Lexington, 2012), 143-53.

${ }^{37} L C A B, 106$, letter to Severn, 7 November 1822.

${ }^{38}$ New Letters from Charles Brown to Joseph Severn, letter 41.

${ }^{39} L C A B, 344$.
} 
earliest public exhibition of 'Keatsiana', complementing Brown's pioneering lecture and his biography; in many respects, Brown's activities at Plymouth, centred on the Institution, marked the beginning of nineteenth-century reassessments of Keats's achievement - an era in the development of his reputation that still shapes modern understandings.

A further push towards recognition was Brown's publication of Keats's poems in two local newspapers: The Plymouth, Devonport, and Stonehouse News and The Plymouth and Devonport Weekly Journal. Between 15 October 1836 and 4 July 1839 he published fifteen of Keats's poems, thirteen of them (in bold below) for the first time:

In the Plymouth, Devonport, and Stonehouse News:

'If by dull rhymes our English must be chain'd' (15 October 1836).

In the Plymouth and Devonport Weekly Journal:

'Sonnet. - To the Nile' (19 July 1838).

'Sonnet, Written on the Summit of Ben Nivis' [sic] (6 September 1838).

'Ailsa Rock: in height 940 feet from the sea, near the Ayrshire Coast' (13 September 1838).

'Fingal's Cave in Staffa.-Fragment' ['Not Aladdin magian'] (20 September 1838).

'Sonnet' ['Bright Star!'] (27 September 1838).

'Sonnet' ['The day is gone'] (4 October 1838).

'Sonnet. - To Sleep' (11 October 1838).

'The Faery Bird's Song' ['Shed no Tear'] (18 October 1838).

'Song' [Spirit here that reignest'] (25 October 1838).

'Faery Dirge’ ['Ah! woe is me! poor Silver-wing!'] (25 October 1838).

‘Sonnet. On Sitting Down to Read King Lear Once Again' (8 November 1838).

'Lines on seeing a Lock of Miltons's Hair' [sic] (15 November 1838). 


\section{'Meg Merrilies. A Ballad, written for the amusement of his young sister' (22 November 1838).}

\section{'In after time' (4 July 1839).}

Except for 'To Ailsa Rock' and 'Fingal's Cave' none of these poems had been published before; the earliest is the 'Lines on seeing a Lock of Milton's Hair', written in January 1818 just after Keats moved into Wentworth Place; four of the poems ('Ben Nevis', 'Ailsa Rock', 'Fingal's Cave' and 'Meg Merrilies') dated from the Scottish tour of summer 1818; 'In after time' Brown said was 'the last stanza, of any kind, that [Keats] wrote before his lamented death'. ${ }^{40}$ The most famous of the poems Brown published is the 'Bright Star' sonnet, possibly about Fanny Brawne and difficult to date precisely. Finally, in October 1840 Brown published his 'Walks in the North', recording the Scottish tour of summer 1818, as a series of four articles in the Plymouth and Devonport Weekly Journal. ${ }^{41}$

An exhibition, a lecture, poems, and 'Walks in the North': all of this amounted to a broadside aimed at the London establishment in London — an establishment that was still largely hostile to Keats's poetry. Brown was understandably anxious that his Keats biography might be 'of little interest except among a few'; the Morning Chronicle turned down his offer to publish it as an article, and he thought of donating the MS to the British Museum. ${ }^{42}$ And so things rested at Plymouth, although Keats's fortunes were turning. In 1840 the London publisher William Smith produced a small collected edition of his poems; a further edition came in the following year, when George Keats waived his rights and agreed to the publication of a Memoir of his brother. Thereafter collected and selected editions of Keats's poems have appeared almost every year; for Brown the change was welcome, but by now his life was about to take a new course. In 1841 he presented his

\footnotetext{
${ }^{40}$ Plymouth and Devonport Weekly Journal (4 July 1839).

${ }^{41} 1,8,15$ and 22 October 1840; see also LJK, i. 421-42.

${ }^{42}$ New Letters from Charles Brown to Joseph Severn, letter 42. LCAB, 406. Life of John Keats by Charles Armitage Brown, 20.
} 
Keats biography and other manuscripts to Richard Monckton Milnes, who used them as the basis for his own Life, Letters and Literary Remains, of John Keats published in 1848.

Brown then migrated to New Zealand where after a brief and outspoken settlement at New Plymouth he died on 5 June, 1842, aged 55.

Between 1818 and 1820 Brown was a central figure in Keats's life. He gives us numerous insights into Keats's life as a writer that we would not have had otherwise indeed, without Charles Armitage Brown, Keats's life would have taken a very different course, such that we would probably not have many of the poems. The 'Nightingale Ode' was written in Brown's garden, and the Eve of St Agnes was written in the house of Brown's friends at Bedhampton: had Keats not been in those places, the poems would not have been written. Keats would not have accompanied Brown on his summer Scottish tour in 1818 , so we would not have his marvellous journal letters to his brothers and poems about Burns, Ailsa Rock, and Ben Nevis. There would be no Hyperion, at least as we know it, for Keats based the scenery of his poem on the Scottish Highlands; had Keats not gone to Winchester with Brown in August 1819, 'To Autumn' would most likely not exist. It goes without saying then, that we would not have Brown's wonderful portrait of Keats, or his recollections of his friend in his lecture and his biography - a biography that is truly irreplaceable, in that it provides information about John Keats unavailable to anyone else. In that respect, one of Brown's most intriguing insights relates to Keats's family, and to his father Thomas Keates - an obscure figure about whom little is known.

Keats's sister Fanny said that their father came from Land's End; Thomas Hardy suggested that he might have come from Dorset — his neighbours at Higher Bockhampton were a family of Keatses, and he was 'struck' by their likeness to the poet. Charles Brown took a different view, that may explain why he 'boldly put down [his] name at our 
Institution for a lecture, on 29 December, on "The life and poems of John Keats"': Keats's father, Brown announced to his audience on that night, was 'a native of Devonshire'. 